\title{
PROBLEMATIKA YANG DIHADAPI LEMBAGA PENDIDIKAN ISLAM SEBAGAI TANTANGAN DALAM MENINGKATKAN MUTU PENDIDIKAN
}

\author{
DANIAL RAHMAN' ${ }^{1}$ ABU RIZAL AKBAR ${ }^{2}$ \\ 1,2 Sekolah Tinggi Ilmu Tarbiyah Al-Chaeriyah Mamuju, Indonesia \\ Email: 1ㅁanial.rahmaan@gmail.com, ${ }^{2}$ aburizalakbar5@gmail.com
}

\begin{abstract}
Problems of Islamic Educational Institutions as Challenges in Improving Quality of Education

This article aims to describe the problems of Islamic educational institutions as challenges in improving the quality of education and constructive efforts to overcome them. Problems that become challenges for Islamic educational institutions in improving quality include: public skepticism towards Islamic educational institutions, weak institutional vision and mission, overloaded curriculum, low competitiveness of graduates of educational institutions, inadequate infrastructure and technology behind, unprofessional teaching and educational staff, as well as the dichotomy of science. Constructive efforts that can be made in improving the quality of Islamic educational institutions as well as being a solution to the problems faced by Islamic educational institutions in improving quality include: building public trust in Islamic education, determining the vision and mission of Islamic education that is mature and in accordance with the Qur'an. and Hadith, designing a curriculum that is in accordance with the needs of the community, producing graduates who have high competitiveness, have adequate facilities and infrastructure and increase competitiveness through science and technology, improve and improve the performance of educators and education, as well as integration between religious and general sciences.
\end{abstract}

Keywords: Islamic Education Institutions, Problems of Islamic Education, Quality of Education

\begin{abstract}
Abstrak: Problematika yang Dihadapi Lembaga Pendidikan Islam sebagai Tantangan dalam Meningkatkan Mutu Pendidikan

Artikel ini bertujuan untuk mendeskripsikan tentang problematika lembaga pendidikan Islam sebagai tantangan dalam meningkatkan mutu pendidikan serta upaya konstruktif dalam menanggulanginya. Problematika yang menjadi tantangan lembaga pendidikan Islam dalam meningkatkan mutu mencakup: sikap skeptis masyarakat terhadap lembaga pendidikan Islam, lemahnya visi dan misi kelembagaan, kurikulum yang overloaded, rendahnya daya saing lulusan lembaga pendidikan, sarana prasarana yang kurang memadai dan ketertinggalan teknologi, tenaga pendidik dan kependidikan yang kurang profesional, serta dikotomi ilmu pengetahuan. Upaya konstruktif yang dapat dilakukan dalam meningkatkan mutu lembaga pendidikan Islam sekaligus menjadi solusi dari problematika yang dihadapi lembaga pendidikan Islam dalam meningkatkan mutu, di antaranya adalah: membangun kepercayaan
\end{abstract}


masyarakat terhadap pendidikan Islam, menentukan visi dan misi pendidikan Islam yang matang dan sesuai dengan al-Qur'an dan Hadis, merancang kurikulum yang sesuai dengan kebutuhan masyarakat, mencetak lulusan yang memiliki daya saing tinggi, memiliki sarana dan prasarana yang memadai serta meningkatkan daya saing melalui IPTEK, memperbaiki dan meningkatkan kinerja tenaga pendidik dan kependidikan, serta keterpaduan antara ilmu agama dan umum.

Kata Kunci: Lembaga Pendidikan Islam, Problematika Pendidikan Islam, Mutu Pendidikan

\section{PENDAHULUAN}

Arus globalisasi yang sedang melanda seluruh penjuru dunia telah memberikan banyak perubahan terhadap kehidupan masyarakat. Globalisasi dapat diartikan sebagai proses penyebaran unsur-unsur baru, khususnya yang menyangkut informasi secara mendunia melalui media cetak maupun elektronik. Globalisasi yang memiliki dua sisi mata uang (positif dan negatif) juga menjadi penyebab infiltrasi budaya yang tidak terbendung. Budaya-budaya yang sedemikian cepat dan mudah saling bertukar tempat dan saling memengaruhi satu sama lain, termasuk budaya hidup barat yang liberal bebas merasuki budaya ketimuran yang lebih cenderung teratur dan terpelihara oleh nilai-nilai agama. Dampak negatif dari arus globalisasi yang terlihat miris adalah perubahan yang cenderung mengarah pada krisis moral dan akhlak sehingga menimbulkan sejumlah permasalahan kompleks yang melanda.

Lembaga pendidikan Islam merupakan lembaga yang digunakan sebagai wadah untuk menanamkan nilai-nilai Islam dalam diri sejumlah peserta didik dan mendasarkan segenap kegiatannya atas pandangan dan nilai-nilai Islam. Namun, meskipun sebagai lembaga yang bercirikan Islam, lembaga pendidikan Islam juga harus memerhatikan pengetahuan umum agar tidak mengalami ketertinggalan dengan lembaga pendidikan pada umumnya. Oleh karena itu, lembaga pendidikan Islam yang ideal adalah yang mampu mengintegrasikan antara ilmu pengetahuan umum dan ilmu pengetahuan keislaman serta mampu menyesuaikan dengan kebutuhan stakeholder pendidikan.

Kondisi saat ini, pendidikan Islam berada pada posisi determinisme historik dan realisme, dalam artian bahwa suatu sisi umat Islam berada pada romantisme historis karena mereka bangga pernah memiliki para pemikir dan ilmuwan besar dan mempunyai kontribusi yang besar pula bagi pembangunan peradaban dan ilmu pengetahuan dunia serta menjadi transmisi bagi khasanah Yunani. Namun, di sisi lain mereka menghadapi sebuah kenyataan bahwa pendidikan Islam tidak berdaya dihadapkan dengan realitas masyarakat industri dan teknologi modern. 
Terjadinya pemilahan-pemilahan antara ilmu umum dan ilmu agama inilah yang membuat umat Islam kepada keterbelakangan dan kemunduran peradaban karena ilmu-ilmu umum dianggap sesuatu yang berada di luar Islam dan berasal dari non-Islam. Begitulah praktik kependidikan dan aktivitas keilmuan di tanah air sekarang ini dengan berbagai dampak negatif yang ditimbulkan dan dirasakan oleh masyarakat. Hal tersebut dapat memicu berbagai tantangan di lembaga pendidikan Islam, termasuk sikap skeptis masyarakat terhadap lembaga pendidikan Islam tersebut.

Masyarakat akan beranggapan bahwa dengan mengkaji ilmu keislaman saja tanpa mengintegrasikannya dengan ilmu-ilmu umum akan mengalami ketertinggalan dari perkembangan zaman, apalagi arus globalisasi semakin melanda di seluruh penjuru yang mengharuskan penguasaan ilmu pengetahuan dan teknologi, sebagaimana dikatakan oleh Wayong (2013, h. 122) bahwa era globalisasi adalah kompetisi. Jika hakekat dari kompetisi adalah keunggulan maka dalam konteks ini akan berlaku teori Darwin "the survival of the fittest". Dengan teori ini akan muncul seleksi alam bahwa pihak yang unggullah yang akan bertahan.

Indonesia sebagai negara yang berpenduduk mayoritas Islam, lembaga pendidikan Islam mempunyai peran yang sangat signifikan dalam pengembangan sumber daya manusia dan pembangunan karakter sehingga masyarakat yang tercipta merupakan cerminan masyarakat Islami. Dengan demikian, Islam benarbenar akan menjadi rahmatan lil'aalamiin. Akan tetapi, sampai saat ini pendidikan Islam masih saja menghadapi permasalahan yang kompleks, mulai dari segi konseptual-teoretis hingga persoalan operasional-praktis. Persoalan-persoalan tersebut menjadikan lembaga pendidikan Islam mengalami ketertinggalan dengan lembaga pendidikan lainnya, baik secara kuantitatif maupun kualitatif sehingga pendidikan Islam terkesan sebagai pendidikan "kelas dua". Dengan demikian, tidak heran jika kemudian banyak dari generasi muslim yang justru menempuh pendidikan di lembaga pendidikan non-Islam.

\section{PEMBAHASAN}

\section{Problematika yang Menjadi Tantangan dalam Meningkatkan Mutu Lembaga Pendidikan Islam}

Eksistensi lembaga pendidikan Islam di Indonesia berdiri dan berkembang di berbagai kota dan daerah di Indonesia. Keberadaannya dapat mulai dari tingkat dasar sampai perguruan tinggi. Akan tetapi, berbagai persoalan-persoalan yang menjadi tantangan lembaga pendidikan Islam hingga saat ini membutuhkan upaya konstruktif untuk menanggulanginya. 


\section{Sikap Skeptis Masyarakat terhadap Lembaga Pendidikan Islam}

Sejalan dengan perkembangan Indonesia, madrasah terus berkembang. Namun, perkembangannya cukup eksklusif karena ilmu pengetahuan agama (Islam) lebih diutamakan. Hal ini menyebabkan madrasah hanya berkembang dalam masyarakat Islam. Ekspansi pun hanya berkisar di daerah pedesaan, sedangkan di perkotaan sangat jarang. Oleh karena itu, keberadaan madrasah lebih banyak di pedesaan dibandingkan di perkotaan sehingga memicu lambannya perkembangan madrasah yang jauh dari atmosfer pembaruan sistem pendidikan, baik kelembagaan maupun sistem dari proses pembelajaran.

Madrasah pada awalnya diharapkan akan mampu mencetak ahli-ahli agama dan para pemimpin Islam mulai diragukan kemampuannya. Walaupun mempunyai kedudukan setaraf dengan sekolah umum, dalam perjalanannya madrasah tetap berbeda dengan sekolah-sekolah umum. Madrasah masih dianggap lembaga pendidikan "kelas dua" karena ada pandangan "daripada tidak sekolah lebih baik masuk madrasah" (Suwito, 2008).

Suasana religius yang memungkinkan dapat tercipta di madrasah daripada di sekolah umum, juga merupakan salah satu poin tersendiri mengapa masyarakat berpandangan positif terhadap madrasah. Namun, masalah ini juga masih belum cukup berhasil secara memuaskan, sebab ciri khas agama Islam yang menjadi label madrasah, masih belum menyentuh pada penanaman dan pengembangan nilainilai religius pada setiap bidang pelajaran yang termuat dalam program pendidikannya.

\section{Lemahnya Visi dan Misi Kelembagaan}

Persoalan penentuan visi dan misi kelembagaan menjadi persoalan urgen yang sering dilupakan oleh pengelola pendidikan. Visi lembaga pendidikan seharusnya sudah dirancang dari awal untuk menjadi payung dilaksanakan proses pembelajaran. Dengan visi dan misi itulah, suatu lembaga pendidikan dapat merencanakan dan menentukan hal-hal yang diperlukan dalam kegiatan pendidikan. Sekarang ini, visi dan misi menjadi masalah serius bagi lembaga pendidikan Islam. Jika ditinjau di lapangan, banyak lembaga khususnya madrasah di Tanah Air tidak memiliki visi atau arah yang jelas mengenai pengelolaan pendidikan yang baik sehingga madrasah belum mempunyai perencanaan dan penataan baik yang mengakibatkan pada tatanan implementasi cenderung berjalan apa adanya (Mutohar, 2013).

Visi dan misi pendidikan tidak hanya sebagai slogan atau sebagai hiasan serta pajangan dinding sekolah saja tetapi memang benar-benar harus dijadikan landasan untuk membawa lembaga pendidikan itu ke arah perbaikan yang disertai dengan adanya inovasi-inovasi didalamnya. Sekolah sebagai salah satu lembaga 
pendidikan yang diberikan tugas untuk mewujudkan tujuan pendidikan nasional harus menjalankan perannya dengan baik. Dalam menjalankan peran sebagai lembaga pendidikan ini, sekolah harus dikelola dengan baik agar dapat mewujudkan tujuan pendidikan yang telah dirumuskan dengan optimal. Pengelolaan sekolah yang tidak profesional dapat menghambat proses pendidikan yang sedang berlangsung dan dapat menghambat langkah sekolah dalam menjalankan fungsinya sebagai lembaga pendidikan formal.

\section{Kurikulum yang Overloaded}

Kurikulum menjadi persoalan yang sangat urgen dalam dunia pendidikan. Kurikulum di madrasah sarat dengan materi (overloaded) dan bahkan tidak memiliki keterikatan antara pelajaran agama dengan pelajaran umum. Kurikulum di madrasah lebih menekankan pada ranah kognitif saja, sementara ranah afektif dan psikomotorik menjadi terabaikan. Seharusnya, kurikulum harus segera diperbaiki karena tanpa kurikulum yang tepat, maka lembaga Pendidikan Islam akan sulit mencapai tujuan pendidikan (Suwito, 2008).

Satu hal yang paling penting dalam masalah pendidikan formal adalah pengaturan kurikulum karena kurikulumlah yang dijadikan sebagai acuan bagi berjalannya proses pendidikan. Bahkan termasuk sebagai acuan bagi evaluasi berhasil atau tidaknya proses kegiatan belajar mengajar yang dilakukan oleh seorang guru atau sekolah. Dengan demikian, pengaturan kurikulum yang sifatnya overloaded akan menghambat peningkatan mutu pendidikan.

Materi pembelajaran yang terdapat dalam kurikulum pendidikan Islam pada masa sekarang nampaknya semakin luas. Hal ini karena dipicu oleh kemajuan ilmu pengetahuan, teknologi dan budaya, selain juga semakin beratnya beban yang ditanggung oleh pihak sekolah sebagai penyelenggara pendidikan. Oleh karena tuntutan perkembangan yang demikian pesatnya, para perancang kurikulum pendidikan Islam juga dituntut untuk memperluas cakupan yang terkandung dalam kurikulum pendidikan Islam, antara lain berkaitan dengan tujuan yang ingin dicapai dalam proses pembelajaran dan pendidikan.

\section{Rendahnya Daya Saing Lulusan Lembaga Pendidikan}

Islam dilihat dari aspek lulusan, lulusan madrasah sangat berbeda dengan lulusan dari sekolah-sekolah umum dimana lulusan sekolah umum memiliki aspek yang lebih terbuka untuk melanjutkan ke perguruan tinggi umum, sedangkan bagi lulusan madrasah memperoleh keterbukaan yang luas hanya pada perguruan tinggi Islam (Mastuhu, 1999). Sebenarnya, madrasah memiliki keunggulan yang lebih dibanding dengan sekolah umum karena muatan pendidikan agama di madrasah lebih banyak daripada di sekolah umum. Ini berarti pendidikan moral 
yang dikandung dalam pendidikan agama lebih banyak diberikan pada madrasah. Namun pada kenyataannya, madrasah masih kurang mampu untuk bersaing dan bersaing dengan lulusan sekolah umum (Suwito, 2008).

Rendahnya investasi pendidikan telah memosisikan kegiatan pendidikan sebagai mesin penghasil manusia "berijazah", namun miskin kompetensi. Lulusan lembaga pendidikan menjadi produk massa, dan program pendidikan lebih diarahkan sebagai program populis ketimbang sebagai program sistematis untuk meningkatkan mutu SDM. Hal ini tidak terlepas dari tarik-menarik kepentingan pendekatan kualitas dan kuantitas dalam kebijakan pendidikan kita.

\section{Sarana dan Prasarana yang Kurang Memadai dan Ketertinggalan Teknologi}

Hal yang menjadi problem dalam pendidikan Islam adalah keterbatasan sarana dan prasarana, baik dari segi bangunan, media pembelajaran, maupun teknologi. Berkenaan dengan tempat, sering dijumpai lembaga Pendidikan Islam (madrasah) yang berada di pedesaan mempunyai gedung yang sudah tidak memungkinkan lagi untuk mengadakan proses pembelajaran (Suwito, 2008). Di samping itu, media pembelajaran yang digunakan untuk mendukung proses belajar mengajar juga kurang memadai. Jika ditinjau dari segi kemajuan sains teknologi, lembaga Pendidikan Islam masih tertinggal jauh dengan sekolah umum lainnya. Dalam kegiatan belajar mengajar, lembaga Pendidikan Islam masih banyak menggunakan metode konvensional tanpa melibatkan sains dan teknologi. Allah swt. berfirman dalam QS al-Dzariyat/51: 56 disebutkan bahwa:

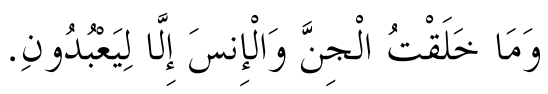

"Dan aku tidak menciptakan jin dan manusia melainkan supaya mereka mengabdi kepada-Ku” (Kementerian Agama RI, 2013; h. 523).

Ayat tersebut seharusnya dipahami secara kontekstual, bukan tekstual. Ibadah merupakan proses penghambaan atau pengabdian seorang makhluk kepada sang Khalik melalui berbagai macam ritual yang umumnya dibatasi pada hal-hal baik ibadah mahdah, seperti shalat, puasa, zakat dan haji, maupun ibadah ghairu mahdah seperti solidaritas sosial, etika politik, kewajiban menuntut ilmu, masalah pergaulan, kepedulian terhadap lingkungan dan alam sekitar, kerja sama antarbangsa, pengembangan sumber daya manusia, dan lain-lain. Penyempitan makna beribadah di sini menimbulkan dampak yang besar atas sikap mereka terhadap sains dan teknologi. Melalui ayat ini, umat Islam berpendapat bahwa sains dan teknologi tidak ada kaitannya dengan kesalehan dan ketakwaan. Padahal dengan pandangan yang tekstual inilah yang menyebabkan umat Islam tertinggal jauh dengan negara lainnya di bidang sains dan teknologi. 
Ketidakefektifan adalah kata yang paling cocok unttuk sistem ini sebab seiring dengan perkembangan zaman, pertukaran informasi menjadi semakin cepat dan instan, namun institut yang masih menggunakan sistem tradisional ini mengajar (di jenjang sekolah tinggi kita anggap memberikan informasi) dengan sangat lambat dan tidak seiring dengan perkembangan IT. Sistem konvensional ini seharusnya sudah ditinggalkan sejak ditemukannya media komunikasi multimedia. Karena sifat Internet yang dapat dihubungi setiap saat, artinya siswa dapat memanfaatkan program-program pendidikan yang disediakan di jaringan Internet kapan saja sesuai dengan waktu luang mereka sehingga kendala ruang dan waktu yang mereka hadapi untuk mencari sumber belajar dapat teratasi. Dengan perkembangan pesat di bidang teknologi telekomunikasi, multimedia, dan informasi; mendengarkan ceramah, mencatat di atas kertas sudah tentu ketinggalan jaman.

\section{Tenaga Pendidik dan Kependidikan yang Kurang Professional}

Tenaga pendidik adalah ujung tombak dalam mencerdaskan kehidupan bangsa, melalui berbagai jenis, jalur dan jenjang pendidikan. Anak didik adalah anggota masyarakat yang akan masuk ke dalam dunia pendidikan (persekolahan) dan akan dikembalikan kepada masyarakatnya. Proses pembekalan komponenkomponen untuk hidup tersebut menjadi tugas guru sebagai tulang punggung di sekolah.

Pendidik akan berhadapan langsung dengan para peserta didik, namun ia tetap memerlukan dukungan dari para tenaga kependidikan lainnya, sehingga ia dapat melaksanakan tugasnya dengan baik. Karena itulah pendidik dan tenaga kependidikan memiliki peran dan posisi yang sama penting dalam konteks penyelenggaraan pendidikan (pembelajaran). Pada dasarnya baik pendidik maupun tenaga kependidikan memiliki peran dan tugas yang sama yaitu melaksanakan berbagai aktivitas yang berujung pada terciptanya kemudahan dan keberhasilan siswa dalam belajar.

Guru merupakan orang yang berada di garda terdepan dan ujung tombak pada proses pendidikan. Hal tersebut disebabkan guru mempunyai posisi sebagai perancang, pelaksana, dan pengevaluasi pembelajaran. Pendidikan akan berhasil dengan baik apabila dilakukan oleh guru yang professional dan bertanggung jawab (Mutohar, 2013). Pada lembaga pendidikan Islam, khususnya madrasah, banyak guru yang mengajar bukan pada bidang keahliannya. Hal ini menjadikan aspek profesionalisme guru terabaikan. Oleh karena itu proses pembelajaran yang berlangsung lebih cenderung pada pola mengajar (teaching, ta'lim) saja, bukan mendidik (education, tarbiyah atau ta'dib). 


\section{Dikotomi Ilmu Pengetahuan}

Saat ini pendidikan dikembangkan dengan memisahkan antara ilmu-ilmu agama dan ilmu-ilmu umum. Para tokoh agama mempunyai pendapat bahwa cukuplah hidup di dunia ini dengan berbekal ilmu agama, walaupun gagap ilmu dan teknologi tidak akan membuat kita merasa terancam dan terasing oleh kehidupan dan justru akan mampu mengendalikan kehidupan dengan baik, bukan sebaliknya dikendalikan oleh kehidupan itu sendiri. Berbeda halnya dengan kehidupan yang hanya dibekali dengan ilmu-ilmu umum saja, mereka akan merasakan kehidupan yang hampa walaupun terlihat nyaman dalam buaian ilmu dan teknologi. Pendidikan Islam selama ini hanyut dalam pemikiran sekuler, sehingga secara tidak sadar melakukan dikotomisasi antara pendidikan keimanan (ilmu-ilmu agama) dengan pendidikan umum (ilmu pengetahuan) dan pendidikan akhlak (etika). Pendidikan sekuler mengembangkan ilmu dengan spesialisasi secara ketat, sehingga keterkaitan dengan ilmu yang lain menjadi hilang, dan melahirkan dikotomi kelompok ilmu agama dan ilmu umum. Pemisahan ini berdampak pada perbedaan sikap di kalangan umat Islam terhadap kedua disiplin ilmu tersebut. Ilmu agama diperlakukan sebagai ilmu Allah yang bersifat sakral dan wajib dipelajari, sedangkan ilmu umum, baik ilmu kealaman maupun sosial bersifat profan dan tidak wajib untuk dipelajari. Hal ini berimbas pada kemunduran umat Islam di bidang ilmu pengetahuan (Abdullah, 2003).

Dengan demikian, terjadi reduksi ilmu agama dan pendangkalan ilmu-ilmu umum. Situasi tersebut membawa akibat ilmu-ilmu agama menjadi tidak menarik karena terlepas dari kehidupan nyata, sedangkan ilmu-ilmu umum berkembang tanpa sentuhan etika dan spiritualitas agama, sehingga kehilangan makna dan bersifat destruktif (Abdullah, 2003). Kehidupan manusia bersifat komplek dan multi dimensi. Keberadaan beragam disiplin ilmu baik ilmu agama, ilmu alam maupun humaniora merupakan upaya manusia untuk memahami kompleksitas dimensi-dimensi hidup manusia. Oleh karena itu, mendalami satu disiplin ilmu saja merupakan sikap yang eklusifarogan, karena satu disiplin ilmu hanya mewakili satu sisi kompleksitas kehidupan manusia.

\section{Upaya Konstruktif dalam Meningkatkan Mutu Lembaga Pendidikan Islam}

Problematika yang terjadi dalam lembaga pendidikan Islam akan terus berkembang jika tidak ditangani secara intensif oleh para pengelola. Dalam mengoptimalkan serta memodernisasi lembaga pendidikan Islam secara serius di masa kini beberapa kemungkinan yang dapat dilakukan, yakni: membangun kepercayaan masyarakat, menentukan visi dan misi pendidikan Islam yang matang dan sesuai dengan al-Qur'an dan Hadis, merancang kurikulum sesuai kebutuhan masyarakat, mencetak lulusan yang berdaya saing, memiliki sarana dan prasarana 
yang memadai serta meningkatkan daya saing melalui IPTEK, memperbaiki dan meningkatkan kinerja tenaga pendidik dan kependidikan, serta keterpaduan antara ilmu agama dan umum.

\section{Membangun Kepercayaan Masyarakat terhadap Pendidikan Islam}

Lembaga pendidikan adalah lembaga yang dibangun di atas cita-cita masyarakat. Sehingga segala program-program yang telah dicanangkan harus diketahui oleh peserta didik dan masyarakat sekitar. Hal ini penting diketahui agar tidak terjadi keresahan pengguna pendidikan pada saat dan sesudah terjadinya proses pembelajaran. Di samping itu, masyarakat juga memiliki tanggung jawab dalam mendukung kesuksesan program-program yang telah disusun lembaga pendidikan. Lembaga pendidikan yang mempunyai kontak hubungan yang baik dengan masyarakat, akan terus maju. Walaupun pada mulanya lembaga pendidikan tersebut belum mempunyai banyak fasilitas dan dana terbatas, namun kemampuan manajemen yang baik dalam mendekati para dermawan, orang-orang yang berpengaruh dan cinta pendidikan, dan himbauan-himbauan yang menarik dan rasional, akan menjadikan masyarakat berbondong-bondong untuk menyekolahkan putra-putrinya ke lembaga pendidikan tersebut (Shulhan \& Soim, 2013).

Selain itu, agar lembaga Pendidikan Islam dapat dipercaya oleh masyarakat untuk menghasilkan output yang unggul, lembaga Pendidikan Islam harus dapat memuaskan masyarakat dan mengetahui terhadap apa yang diinginkan oleh masyarakat, bukan semata-mata hanya memasang iklan dan promosi yang mengelabuhi masyarakat agar tertarik dengan program-program yang ditawarkan. Akan tetapi, lembaga Pendidikan Islam harus mampu meyakinkan dan membuktikan kepada masyarakat sebagai konsumen pendidikan bahwa lembaga Pendidikan Islam benar-benar bermutu (Mutohar, 2013). Oleh karena itu, lembaga Pendidikan Islam harus mempunyai standar mutu yang diinginkan dan programprogram mutu yang ditawarkan kepada masyarakat pengguna lembaga pendidikan. Program-program mutu ini harus disertai dengan standar mutu yang telah ditetapkan serta perlu adanya perencanaan strategis dan profesionalitas SDM yang menjalankan program-program mutu tersebut.

\section{Menentukan Visi dan Misi Pendidikan Islam yang Matang dan Sesuai dengan al-Qur'an dan Hadis}

Untuk mewujudkan pendidikan yang berkualitas dan berdaya saing tinggi, visi lembaga Pendidikan Islam harus dirumuskan berdasarkan tujuan pendidikan Islam, harapan dan keinginan masyarakat dan stakeholders pendidikan serta memuat cita-cita yang luhur dalam mewujudkan Pendidikan Islam yang 
berkualitas. Ibnu Khaldun merumuskan tujuan atau visi pendidikan Islam dengan berlandaskan QS al-Qashash/28: 77 berikut ini.

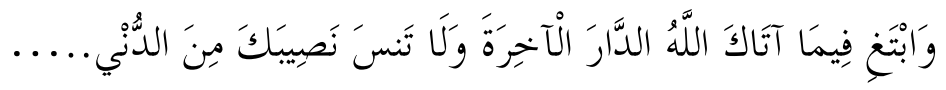

"Dan carilah pada apa yang telah dianugerahkan Allah kepadamu (kebahagiaan) negeri akhirat, dan janganlah kamu melupakan bahagianmu dari (kenikmatan) duniawi...." (Kementerian Agama RI, 2013; h. 394).

Berdasarkan firman Allah tersebut, Ibnu Kaldun dalam Abdul Mujib dan Jusuf Mudzakkir merumuskan bahwa tujuan Pendidikan Islam terbagi menjadi dua macam, yaitu: (1) tujuan yang berientasi ukhrawi, yaitu membentuk seorang hamba agar melakukan kewajiban kepada Allah; (2) tujuan yang berorientasi duniawi, yaitu membentuk manusia yang mampu menghadapi segala bentuk kebutuhan dan tantangan kehidupan, agar hidupnya lebih layak dan bermanfaat bagi orang lain (Mujib \& Mudzakkir, 2008). Adapun misinya adalah pernyataan mengenai hal-hal yang harus dicapai oleh lembaga pendidikan bagi pihak-pihak yang berkepentingan pada saat ini dan di masa yang akan datang. Oleh karena itu, misi harus mencerminkan mengenai sesuatu untuk bisa mencapai visi dengan kata lain misi merupakan penjabaran realitas yang dilakukan lembaga pendidikan dalam meraih visi. Setelah mempunyai visi dan misi yang matang, lembaga Pendidikan Islam juga harus mempunyai kepemimpinan yang visioner sehingga visi dan misi dapat disosialisasikan dan ditansformasikan kepada civitas akademika dan masyarakat agar visi dan misi dapat berjalan dengan baik.

\section{Merancang Kurikulum yang Sesuai dengan Kebutuhan Masyarakat}

Lembaga Pendidikan Islam seharusnya memiliki kurikulum yang didasarkan pada pandangan tentang tidak adanya dikotomi antara ilmu agama dan ilmu umum, dunia dan akhirat. Kurikulum ini terus dikembangkan dari waktu ke waktu sejalan dengan tuntutan masyarakat, perkembangan ilmu pengetahuan dan teknologi, serta tuntutan dunia kerja. Dengan demikian, terjadi hubungan yang sinergis antara lembaga Pendidikan Islam dengan masyarakat.

Manajemen kurikulum yang baik akan berdampak pad output peserta didik yang baik pula. Lembaga pendidikan yang menghasilkan output yang baik akan menarik minat masyarakat terhadap lembaga tersebut sehingga mereka akan menyekolahkan anak-anaknya di sana karena mereka percaya bahwa lembaga pendidikan tersebut memiliki mutu yang bagus.

\section{Mencetak Lulusan yang Memiliki Daya Saing Tinggi}

Lembaga pendidikan yang bermutu adalah mereka mampu membelajarkan peserta didik secara efektif, sesuai dengan kendala, sumber daya, dan 
lingkungannya. Di lain pihak, upaya menghasilkan guru yang bermutu juga merupakan tugas yang tidak mudah. Mutu guru juga berarti tenaga pengajar yang mampu melahirkan lulusan yang bermutu, sesuai dengan kebutuhan penyelenggaraan berbagai jalur, jenis, dan jenjang pendidikan. Di lain pihak, mutu guru sangat berkaitan dengan pengakuan masyarakat akan status guru sebagai jabatan profesional.

Untuk mencetak output yang memiliki daya saing tinggi, harus didukung oleh proses belajar mengajar yang berbasis pada pemberdayaan para siswa (student centrist), yaitu proses pembelajaran yang lebih interaktif, inspiratif, menggairahkan, menantang, memotivasi peserta didik untuk aktif, menumbuhkan prakarsa, kreativitas, kemandirian, sesuai dengan bakat dan minat, serta memberi keteladanan. Melalui proses belajar mengajar yang demikian, diharapkan dapat melahirkan lulusan yang unggul, terberdayakan, serta penuh percaya diri (Nata, 2012).

Manusia yang berkualitas adalah SDM yang komperhensif dalam berfikir dan selalu mengantisipasi tuntutan di masa depan, memiliki sikap positif, berperilaku terpuji, dan berwawasan, serta memiliki kemampuan, keterampilan, dan keahlian yang sesuai dengan kebutuhan diberbagai bidang serta sektor pembangunan. Kualitas dari output lembaga pendidikan sangat dibutuhkan sebagai upaya peningkatan daya saing lembaga pendidikan yang mampu mencetak lulusan yang berkualitas.

\section{Memiliki Sarana dan Prasarana yang Memadai serta Meningkatkan Daya Saing melalui IPTEK}

Lembaga Pendidikan Islam harus memiliki sarana dan prasarana yang sesuai standar pendidikan nasional. Misalnya ruang belajar yang baik dan mencukupi, tempat olahraga, tempat ibadah, perpustakaan, laboratorium, serta sumber belajar lainnya yang menunjang proses pembelajaran termasuk penggunaan teknologi informasi dan komunikasi (Nata, 2012). Selain itu, untuk meningkatkan daya saing lembaga Pendidikan Islam dalam menghasilkan karya-karya bermutu sebagai hasil penguasaan ilmu pengetahuan dan teknologi, harus dimulai dari memperbaiki mutu lembaga Pendidikan Islam secara terus-menerus agar bisa memenuhi tuntutan dan kebutuhan masyarakat secara luas dan sebagai upaya untuk merespon perkembangan ilmu pengetahuan dan teknologi (Nata, 2012).

Tidak dapat dipungkiri bahwa dalam proses pendidikan dan kualitas pendidikan tersebut juga di dukung dengan sarana dan prasarana yang menjadi standar sekolah atau instansi pendidikan yang terkait. Sarana dan prasarana sangat mempengaruhi kemampuan peserta didik dalam belajar. Hal ini menunjukkan bahwa peranan sarana dan prasarana sangat penting dalam 
menunjang kualitas belajar peserta didik. Misalnya saja sekolah yang berada di kota yang sudah memiliki fasilitas laboratorium komputer maka peserta didiknya secara langsung dapat belajar komputer, sedangkan sekolah yang berada di desa tidak memiliki fasilitas itu dan tidak tahu bagaimana cara menggunakan komputer kecuali mereka mengambil kursus di luar sekolah.

Pengelolaan itu dimaksudkan agar dalam menggunakan sarana dan prasarana di sekolah bisa berjalan dengan efektif dan efisien. Pengelolaan sarana dan prasarana merupakan kegiatan yang amat penting di sekolah karena keberadaannya akan sangat mendukung terhadap suksesnya proses pembelajaran. Dalam mengelola sarana dan prasarana di sekolah dibutuhkan suatu proses sebagaimana terdapat dalam manajemen yang ada pada umumnya, yaitu mulai dari perencanaan, pengorganisasian, penggerakan, pemeliharaan dan pengawasan. Apa yang dibutuhkan oleh sekolah perlu direncanakan dengan cermat berkaitan dengan sarana dan prasarana yang mendukung semua proses pembelajaran.

\section{Memperbaiki dan Meningkatkan Kinerja Tenaga Pendidik dan Kependidikan}

Tindakan untuk memajukan lembaga pendidikan membutuhkan tenaga pendidik dan kependidikan yang profesional, yakni sumber daya manusia yang mempunyai keilmuan yang luas dan mendalam yang didukung oleh latar belakang pendidikan yang relevan serta mempunyai kemampuan untuk mendidik (education, tarbiyah atau ta'dib) atau mengamalkan ilmunya. Selain itu, tenaga pendidik dan kependidikan juga harus mempunyai kepribadian yang baik serta memiliki etos kerja tinggi sehingga dapat menjadi teladan bagi peserta didik. Guru yang professional dapat menunjukkan kinerja yang produktif. Kinerja yang produktif sangat dibutuhkan karena produktivitas merupakan salah satu indikator yang harus dipenuhi dalam meningkatkan mutu lembaga pendidikan. Hasil kinerja guru tercermin pada hasil belajar atau prestasi yang diraih peserta didik. Oleh karena itu, perlu dilakukan upaya-upaya untuk meningkatkan kinerja guru, misalnya dengan melakukan supervisi, kegiatan ilmiah, studi lanjut dan penilaian kinerja guru (Mutohar, 2013).

Suatu lembaga pendidikan dapat menghasilkan outputyang bagus jika memiliki tenaga pendidik dan kependidikan yang berkualitas. Begitupun sebaliknya tenaga pendidik yang kurang berkualitas jangan harap akan menghasilkan lulusan yang berkualitas sebagaimana istilah dalam bahasa arab "orang yang tidak memiliki sesuatu tidak akan memberi apapun."

\section{Keterpaduan antara Ilmu Agama dan Umum}

Keterpaduan antara berbagai disiplin ilmu perlu dilakukan, tanpa harus mengorbankan spesialisasi yang menjadi ciri masyarakat modern. Spesialisasi 
harus dilakukan dalam hubungannya dengan pembidangan secara teknis karena setiap orang tidak mungkin dapat menguasai keahlian dalam berbagai bidang disiplin ilmu. Namun spesialisasi harus ditempatkan dalam rangka menjalin hubungan antara satu ilmu dengan lainnya, dalam hal ini antara ilmu agama dan ilmu umum. Keterpaduan antara ilmu agama dan umum akan menimbulkan konsep islamisasi atau integrasi-interkoneksi ilmu pengetahuan. Islamisasi ilmu pengetahuan ini sangat signifikan dalam mengatasi dualisme antara ilmu agama dan ilmu umum (Nata, 2012). Landasan teologis integrasi interkoneksi ilmu terdapat dalam QS al-Mujaadilah/58: 11 berikut ini:

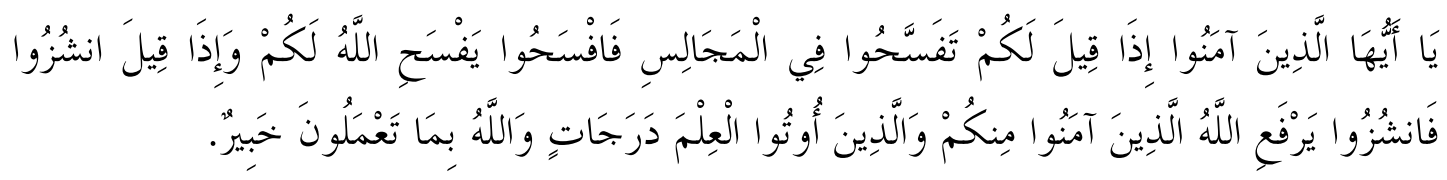

"Hai orang-orang beriman apabila kamu dikatakan kepadamu: "Berlapanglapanglah dalam majlis", Maka lapangkanlah niscaya Allah akan memberi kelapangan untukmu. dan apabila dikatakan: "Berdirilah kamu", Maka berdirilah, niscaya Allah akan meninggikan orang-orang yang beriman di antaramu dan orang-orang yang diberi ilmu pengetahuan beberapa derajat. dan Allah Maha mengetahui apa yang kamu kerjakan" (Kementerian Agama RI, 2013; h. 543).

Kata-kata kunci yang bisa ditarik dari ayat tersebut adalah iman, ilmu, dan amal. Ketiganya menjadi satu rangkaian sistemik dalam struktur kehidupan setiap muslim. Dalam konteks pendidikan Islam, iman, ilmu, dan amal harus menjadi prioritas dibandingkan kognitif, afektif, psikomotorik maupun normatif. Integrasiinterkoneksi bertujuan untuk mengkaji berbagai disiplin keilmuan serta merumuskan keterpaduan dan keterikatan antar disiplin ilmu sebagai jembatan untuk memahami kompleksitas hidup manusia, sehingga dapat meningkatkan kualitas hidup, baik dalam aspek material, moral, maupun spiritual (Abdullah, 2003). Pada dasarnya, Islam mengembangkan ilmu yang bersifat universal dan tidak mengenal dikotomi ilmu qauliyyah hadarah al-nash (ilmu yang berkaitan dengan teks keagamaan) dengan ilmu kauniyyah-ijtima"iyyah/hadarah al-ilm (ilmu kealaman dan kemasyarakatan), maupun dengan had\}arah al-falsafah (ilmu etis-filosofis). Hubungan ilmu agama dan sains sangat penting dewasa ini (Hoodbhoy, 1997). Dengan demikian, ilmu-ilmu tersebut saling berinteraksi, saling memperbincangkan, saling menghargai atau mempertimbangkan serta sensitif terhadap kehadiran ilmu yang lain. Dengan demikian, dikotomi ilmu pengetahuan menjadi tidak ada dan struktur keilmuan bersifat reintegrasi epistemologi keilmuan. 


\section{PENUTUP}

Problematika yang menjadi tantangan lembaga pendidikan Islam dalam meningkatkan mutu mencakup: sikap skeptis masyarakat terhadap lembaga pendidikan Islam, lemahnya visi dan misi kelembagaan, kurikulum yang overloaded, rendahnya daya saing lulusan lembaga pendidikan, sarana prasarana yang kurang memadai dan ketertinggalan teknologi, tenaga pendidik dan kependidikan yang kurang profesional, serta dikotomi ilmu pengetahuan.

Upaya konstruktif yang dapat dilakukan dalam meningkatkan mutu lembaga pendidikan Islam sekaligus menjadi solusi dari problematika yang dihadapi lembaga pendidikan Islam dalam meningkatkan mutu, di antaranya adalah: membangun kepercayaan masyarakat terhadap pendidikan Islam, menentukan visi dan misi pendidikan Islam yang matang dan sesuai dengan al-Qur'an dan Hadis, merancang kurikulum yang sesuai dengan kebutuhan masyarakat, mencetak lulusan yang memiliki daya saing tinggi, memiliki sarana dan prasarana yang memadai serta meningkatkan daya saing melalui IPTEK, memperbaiki dan meningkatkan kinerja tenaga pendidik dan kependidikan, serta keterpaduan antara ilmu agama dan umum.

\section{DAFTAR PUSTAKA}

Abdullah, A. (2003). Menyatukan Kembali Ilmu-Ilmu Agama dan Umum. Yogyakarta: UIN Sunan Kalijaga Press.

Hoodbhoy, P. (1997). Islam dan Sains. Bandung: Pustaka Setia.

Kementerian Agama RI. (2013). Al-Qur'an dan Terjemahan. Bandung: Mikhraj Khazanah Ilmu.Mastuhu. (1999). Memberdayakan Sistem Pendidikan Islam. Jakarta: Logos.

Mujib, A., \& Mudzakkir, J. (2008). Ilmu Pendidikan Islam. Jakarta: Kencana.

Mutohar, P. M. (2013). Manajemen Mutu Sekolah. Yogyakarta: Ar-Ruzz Media.

Nata, A. (2012). Manajemen Pendidikan. Jakarta: Prenada Media Group.

Shulhan, M., \& Soim. (2013). Manajemen Pendidikan Islam. Yogyakarta: Teras.

Suwito. (2008). Sejarah Sosial Pendidikan Islam. Jakarta: Prenada Media Group.

Wayong, M. (2013). Manajemen Kontemporer: Sebuah Pendekatan Global. Makassar: Alauddin University Press. 